Delorme, T.C., Srivastava, L.K., Cermakian, N. (2020) Are circadian disturbances a core pathophysiological component of schizophrenia? Journal of Biological Rhythms, 35(4):325-339. https://doi.org/10.1177/0748730420929448 @ 2020 the authors under a Creative Commons License CC-BY-NC-ND

\title{
Are circadian disturbances a core pathophysiological component of schizophrenia?
}

Running title: Circadian rhythms and schizophrenia

Tara C. Delorme ${ }^{*, \dagger}$, Lalit K. Srivastava $a^{\dagger, \ddagger}$ and Nicolas Cermakian ${ }^{\dagger, \star 1}$

*Integrated Program in Neuroscience, McGill University, Montréal, Québec, H3A 1A1.

${ }^{\dagger}$ Douglas Mental Health University Institute, Montréal, Québec, H4H 1R3.

\$ Department of Psychiatry, McGill University, Montréal, Québec, H3A 1A1.

\author{
${ }^{1}$ Author for correspondence: \\ Dr. Nicolas Cermakian \\ 6875 Boulevard LaSalle, Montreal, QC H4H 1R3, Canada \\ Phone: 514-761-6131 ext. 4936 \\ E-mail: nicolas.cermakian@mcgill.ca
}




\begin{abstract}
Schizophrenia is a multifactorial disorder caused by a combination of genetic variations and exposure to environmental insults. Sleep and circadian rhythm disturbances are a prominent and ubiquitous feature of many psychiatric disorders, including schizophrenia. There is growing interest in uncovering the mechanistic link between schizophrenia and circadian rhythms, which may directly impact disorder outcomes. In this review, we explore the interaction between schizophrenia and circadian rhythms from two complementary angles. First, we review evidence that sleep and circadian rhythm disturbances constitute a fundamental component of schizophrenia, as supported by both human studies and by animal models with genetic mutations related to schizophrenia. Second, we discuss the idea that circadian rhythm disruption interacts with existing risk factors for schizophrenia to promote schizophrenia-relevant behavioral and neurobiological abnormalities. Understanding the mechanistic link between schizophrenia and circadian rhythms will have implications for mitigating risk to the disorder and informing the development of circadian-based therapies.
\end{abstract}

Keywords: schizophrenia, circadian rhythm, risk factor, interaction, sleep, animal model 


\section{Introduction}

Schizophrenia is a severe and chronic neurodevelopmental disorder, with a lifetime prevalence of close to $1 \%$ (Jablensky, 2000; McGrath et al., 2008). It is typically diagnosed in early adulthood with characteristic positive symptoms (i.e., delusions, hallucinations), negative symptoms (i.e., affective, avolition) and impaired cognition (i.e., learning, attention) (Tandon et al., 2013). Much attention has been given to the hypothesis that schizophrenia is a multifactorial disorder, triggered by a combination of risk factors including gene variants, as well as environmental insults that one is exposed to in utero and during their lifetime (van Os et al., 2008; Ayhan et al., 2016; Stilo and Murray, 2019). Risk factors for schizophrenia are believed to have a small individual impact; most likely, multiple risk factors act synergistically along the lifespan to affect disorder onset, symptoms and course of the disorder. Thus, such risk factors should be studied as an integrated system (Jablensky, 2010). The complexity of the disorder is also reflected in the limited pharmacological treatment options available. Although the antipsychotic drugs, working principally on dopamine system, are effective in controlling positive and some negative symptoms, they rarely improve cognitive and social dysfunctions that are better predictors of functional outcomes (Miyamoto et al., 2005; Kahn et al., 2015). Discovering more efficient therapeutic options may rely on exploring novel risk factors for schizophrenia and uncovering the complex mechanisms in which these risk factors interact to jointly exert their effect.

In the context of schizophrenia, a promising avenue of study is sleep and the circadian system. Indeed, disturbances in these systems are a prominent and ubiquitous feature of many psychiatric disorders, including schizophrenia (Wulff et al., 2010; Wulff et al., 2012; Jagannath et al., 2013; Monti et al., 2013; Kaskie et al., 2017; Logan and McClung, 2019). In a healthy individual, the sleep/wake cycle displays a characteristic 24-hour periodicity and is the most 
documented output of the circadian (daily) system. Circadian clocks are cell autonomous, producing rhythms with a period of $\sim 24$ hours, but can also be entrained by external timing cues (Zeitgebers), such as light. The proper alignment of circadian clocks to environmental cycles is essential for organisms to anticipate and prepare for local challenges, and directly affects the fitness and longevity of many species (Evans and Davidson, 2013). In mammals, a 'master' circadian clock is located in the hypothalamic suprachiasmatic nucleus ( $\mathrm{SCN})$, which receives photic information directly from the retina (Hastings et al., 2018). The SCN clock is formed by many single-cell circadian oscillators that synchronize with one another to generate coordinated circadian outputs (Hastings et al., 2018). Circadian clocks are also located in most other tissues and organs. These 'peripheral' clocks can also function in an autonomous manner. However, they can be reset or synchronized by rhythmic cues that are directly or indirectly controlled by the SCN (Dibner et al., 2010; Hastings et al., 2018).

In this review, we explore the interaction between schizophrenia and circadian rhythms from two complementary angles. First, we assert that sleep and endogenous circadian rhythm disturbances are a fundamental component of schizophrenia. Second, we discuss the idea that environmental and genetic circadian rhythm disruption interacts with risk factors for schizophrenia to promote schizophrenia-relevant behavioral and neurobiological abnormalities.

\section{Sleep and circadian disturbances constitute a fundamental component of schizophrenia}

\section{Sleep and circadian disturbances in patients with schizophrenia}

Sleep disturbances in individuals with schizophrenia have been documented as early as the $19^{\text {th }}$ century by Kraepelin, with 'care for sleep' being a recommended treatment (Kraepelin et al., 1919). In line with these observations, recent findings using more objective experimental tools 
have confirmed that various sleep and circadian disturbances appear highly prevalent in individuals with schizophrenia (Figure 1). Indeed, up to $80 \%$ of individuals with schizophrenia exhibited difficulties with sleep (Cohrs, 2008) and sleep disturbances preceded prodromal psychotic symptoms in over $77 \%$ of patients (Tan and Ang, 2001). Sleep disturbances in subjects with schizophrenia included reduced slow-wave sleep, reduced total sleep time and efficiency, and increased rapid eye movement sleep latency that persisted after accounting for medication, social isolation and the absence of a social routine (Chouinard et al., 2004; Wulff and Joyce, 2011; Zanini et al., 2013). In individuals with schizophrenia, poorer sleep quality correlated with greater symptom severity (Korenic et al., 2019; Laskemoen et al., 2019) and patients with disturbed circadian rhythms performed worse in cognitive tests compared to patients with normal circadian rhythms (Bromundt et al., 2011). In a study measuring both actigraphy and melatonin rhythms, a substantial portion of individuals with schizophrenia had severe disruptions of the circadian sleepwake timing. This included delayed and/or free-running sleep-wake cycles, compared to matched healthy subjects (Wulff et al., 2012). A meta-analysis of sleep parameters accessed by actigraphy reported various sleep disturbances in patients with treated and remitted schizophrenia compared to healthy controls. These included: greater total sleep time, longer time in bed, greater sleep latency, greater wake after sleep onset and reduced motor activity (Meyer et al., 2020).

Further, some reports have outlined an association between psychosis and sleep and circadian disturbances (Reeve et al., 2015; Freeman et al., 2017; Waite et al., 2019). This association was mainly studied in healthy participants, however, preliminary research showed that sleep disturbances are especially prevalent in clinical high risk (CHR) individuals for psychosis (Poe et al., 2017). Using actigraphy and sleep diaries, youth with CHR for psychosis had more fragmented diurnal rhythms and later onset of nocturnal rest than controls, and the level of these disruptions predicted psychosis symptom severity one year later (Lunsford-Avery et al., 2017). 
Using wrist actimetry, older individuals with schizophrenia were found to spend more time in bed, had more fragmented sleep and were awake more during the day compared to older non-psychiatric individuals (Martin et al., 2001; Martin et al., 2005). Of note, the sparsity of research exploring aging and sleep and circadian rhythms in individuals with schizophrenia likely speaks to the challenges in conducting longitudinal studies in patients. The clinical findings summarized above suggest that sleep and circadian disturbances are likely a characteristic feature of schizophrenia, potentially involved in the development of the disorder.

With respect to the molecular markers of the circadian clock, individuals with chronic schizophrenia were found to have a loss of rhythmic mRNA expression of the clock genes CRYPTOCHROME1 (CRY1) and PERIOD2 (PER2) in skin fibroblasts cultured ex vivo and subjected to a clock synchronizing treatment (Johansson et al., 2016). In the same study, blood mononuclear cells from patients experiencing their first episode of psychosis had decreased expression of CRY1, PER2 and CLOCK, compared to controls (Johansson et al., 2016). Further, using RNA sequencing, Seney and colleagues explored gene expression in the dorsolateral prefrontal cortex (dIPFC) of postmortem brains of subjects with schizophrenia. Using time of death data from each subject, researchers found that the set of genes with daily rhythms in subjects with schizophrenia were very distinct from those identified in the dIPFC in healthy controls, and had a different rhythmic pattern (Seney et al., 2019). Distinct cellular pathways were enriched among genes of each of these rhythmic groups. Therefore, this kind of studies might point towards the molecular underpinnings of circadian disturbances in schizophrenia.

Overall, while current evidence highlights the prevalence of sleep and circadian disturbances in individuals with schizophrenia, further studies would benefit from measuring additional biological markers of the endogenous circadian clock and peripheral clocks in individuals with schizophrenia over an extended period of time. 


\section{Targeting sleep and circadian disruptions for therapeutic intervention}

In a clinical setting, sleep and circadian disruptions are seldom assessed or targeted directly for treatment in individuals with schizophrenia, despite 'sleeping better' being a desired treatment preference (Freeman et al., 2019). Luthringer and colleagues were among the first to explore the effects of the antipsychotic treatment, paliperidone ER, on sleep parameters in patients with schizophrenia. Interestingly, they found that patients showed improved sleep architecture and continuity after paliperidone ER treatment (Luthringer et al., 2007). A recent study by Mishra and colleagues explored the sleep-promoting drug ramelteon, a MT1/MT2 melatonin receptor agonist, as an add-on treatment for schizophrenia patients (Mishra et al., 2020). Compared to patients that received antipsychotics alone (haloperidol and risperidone), add-on ramelteon appeared to significantly improve sleep, as well as the severity of positive and negative symptoms. This was accompanied by increased levels of serum melatonin and aryl-alkylamine- $\mathrm{N}$-acetyl-transferase (the rhythmically-expressed and rate-limiting enzyme in the melatonin synthesis pathway) and urinary melatonin (Mishra et al., 2020). Cognitive behavioral therapy for insomnia (CBT-I) is emerging as an effective sleep promoting therapy for individuals with schizophrenia who experience insomnia. CBT-I was most effective in patients with 'classic severe insomnia', denoted by short sleep duration, very poor sleep efficiency and prolonged sleep onset latency (Chiu et al., 2018), and the benefits on sleep in patients were shown to last 4 weeks post treatment (Hwang et al., 2019). Additionally, in male patients admitted to a psychiatric ward, CBT-I, in combination with controlling light/dark exposure and discussion on sleep monitoring, led to larger reductions in selfreported insomnia symptoms and earlier discharge compared to standard care alone (Sheaves et al., 2018). Future studies should conduct a more detailed assessment of the role of different antipsychotics and sleep or circadian-promoting therapies or drugs on symptom severity in 
individuals with schizophrenia and related animal models. For example, one could hypothesize that promoting a proper phase relationship between the circadian system and environmental timing cues may improve schizophrenia-related symptoms by strengthening and stabilizing circadian rhythmicity.

The studies above demonstrate a high prevalence of sleep and circadian disturbances among patients with schizophrenia, which may highlight these disturbances as a core component of schizophrenia pathology. Despite this seemingly high prevalence, there is surprisingly little research targeting these disruptions for therapeutic intervention, leaving much to be discovered.

\section{[INSERT FIGURE 1]}

\section{Animal models to study sleep and circadian disturbances in relation to schizophrenia}

A number of animal models exploring genetic risk factors for schizophrenia have been used in an attempt to reproduce the sleep and circadian disruptions seen in individuals with schizophrenia (Figure 1; see Table 1 for an overview of the animal models related to schizophrenia that have been studied for sleep and circadian phenotypes). Overall, the studies provide insights on a link between schizophrenia risk genes in animal models and sleep and circadian rhythm-related phenotypes. Some of the genes mutated in the mouse models — or related genes — (including GRM3, SNAP91, TSNARE1 and EGR1) were highlighted in a multi-stage schizophrenia genomewide association study (GWAS) (Schizophrenia Working Group of the Psychiatric Genomics Consortium, 2014).

Interestingly, most of the genes or proteins of interest in these mouse models have related cellular functions, namely, in neuronal communication and/or protein and vesicle trafficking. 
Indeed, disrupted synaptic connectivity and function and abnormal neurotransmitter release have been suggested as key factors in the pathogenesis of schizophrenia (Frankle et al., 2003; Harrison and Weinberger, 2005). Notably, SNAP-25 is a SNARE (soluble $N$-ethylmaleimide-sensitive factor attachment protein receptor) associated protein, with a role in the docking of synaptic vesicles at the presynaptic terminal membrane, resulting in fusion and neurotransmitter release (Mohrmann et al., 2010). Dysbindin-1 is a SNARE-modulating presynaptic protein, essential for synaptic homeostasis (Dickman and Davis, 2009). Dysbindin-1 has been reported to modulate Snap-25 expression through a possible interaction with Snapin (Feng et al., 2008) and it might regulate dopamine release in the central nervous system through its actions on the SNARE complex (Kumamoto et al., 2006). Dysbindin-1 and Pallidin also have related mechanisms; they are both subunits in the BLOC-1 (the biogenesis of lysosome-related organelles complex-1) stable protein complex. It was hypothesized that they exert their effects on phenotypes via affecting BLOC-1 stability (Lee et al., 2018).

Dysfunction of vesicle trafficking and synaptic communication may contribute to the pathogenesis of schizophrenia but also to the mechanism underlying the interaction between schizophrenia and sleep and circadian rhythms. The studies presented in Table 1 are mainly descriptive reports, and future studies should aim to uncover mechanistic links between schizophrenia and the sleep and circadian systems.

\section{The challenge of modeling schizophrenia in animal models}

A limitation of studying risk factors for schizophrenia in animal models is the difficulty in faithfully recapitulating the etiological factors and behavioral phenotypes that are often heterogenous and uniquely human. It is widely accepted that the pathogenesis of schizophrenia is explained by a complex interaction between multiple interacting genetic and environmental risk 
factors. Such risk factors are thought to act synergistically, affecting brain development early in life. Thus, the outcome is first seen in young adulthood. A limitation in the studies discussed in Table 1 is that most only utilized animal models with monogenic mutations, that likely only have a small impact on the pathology of schizophrenia. Studying interacting risk factors for schizophrenia as an integrated system would be more appropriate. However, this is posing various challenges, including complicated experimental designs and data analyses.

While no animal model can recapitulate the full intricacies of schizophrenia, they are nonetheless an essential hypothesis-testing preclinical tool. Animal models can be genetically or pharmacologically engineered. Moreover, they offer a high level of experimental control that is necessary when exploring mechanistic links and testing therapeutic targets. Therefore, such studies remain necessary, but should be more and more refined to try accounting for the complex nature of schizophrenia.

\section{Distinguishing Sleep vs. Circadian Rhythm Phenotypes}

Sleep/wake cycles and circadian rhythms involve interconnected yet distinct biological mechanisms. However, it is difficult to disentangle these two phenomena, especially when attempting to measure sleep and circadian phenotypes in animal models. The sleep/wake cycle is one of the most documented outputs of the circadian system. Sleep regulation involves a circadian component, whereby the SCN circadian clock controls the activity of brain sleep- and wakepromoting centers (Saper et al., 2005). Sleep regulation also involves a homeostatic component, whereby the sleep pressure (need for sleep) experienced by an individual, increases with extended wakefulness and dissipates with sleep (Borbely, 2009).

In a stable and predictable environment, the sleep/wake cycle is aligned with other circadian-regulated rhythms in the organism. However, a distinction between the two becomes 
apparent when either cycle is disrupted. The studies presented in Table 1 highlight the dichotomy between the sleep/wake cycle and circadian system, as several mouse models, including Egr3, DISCl and Grm2/3, showed disruptions in one system and not in the other, perhaps shedding light on distinct biological mechanisms that lead to these disruptions.

\section{Comparing Animal Models: Different Assays, Different Methods}

Comparing the sleep and circadian phenotypes of various mouse models across studies is difficult due to the different assay(s) used and non-standardized experimental protocols for data collection and analysis. First, measuring sleep stages in rodent models can be done using electroencephalography (EEG) and electromyography (EMG), or general sleep can be measured less invasively through motion detection, whereby sleep is defined by a bout of immobility. Measuring circadian rhythms in rodent models can also be done in multiple ways, such as through wheel running assessment, bioluminescence recordings and by measuring other markers of the circadian clock such as body temperature and clock gene expression. Thus, the observed effects depend on the assays chosen, which needs to be considered when making comparisons between studies (Pritchett et al., 2012).

Second, experimental conditions, such as wavelength composition and intensity of light, and the type and order of light challenges, and data analysis measures are important to standardize between studies. For example, light challenges can be tested in the following order: first, a standard lighting condition of 12 hours of light and 12 hours of dark (LD), then proceed to phase shifts (delay and/or advance) and constant conditions (constant darkness [DD], constant light [LL]). LL exposure is known to induce desynchrony between the neurons of the SCN (Ohta et al., 2005), thus it is beneficial for this to be the last lighting conditions the animals are exposed to. 
The goal when comparing animal models is to confidently attribute the different phenotypes observed to the different genetic mutations. This can be promoted by using a wide range of assays, standardizing variables related to the experimental conditions, using various lighting conditions and analyzing multiple measures in the data.

Genes or proteins of interest for schizophrenia linked also to sleep and circadian rhythms

While all of the animal models in Table 1 are associated with schizophrenia, a subset of the genes involved are also linked to sleep or the circadian system. Below we discuss how these models are related to sleep or circadian rhythms and the implications of this.

Briefly, Snap-25 has a rhythmic 24-hour pattern of expression in the rodent SCN (Panda et al., 2002). Secondly, Egr3 appears to regulate sleep homeostasis through the serotonin 2 A receptor (5-HT $\left.{ }_{2 \mathrm{a}} \mathrm{R}\right)$ (Maple et al., 2015; Gronli et al., 2016). Indeed, dysfunction of the 5-HT $2 \mathrm{a}$ may be involved in the pathogenesis (Hurlemann et al., 2005) and/or treatment of schizophrenia (Garay et al., 2016). Egr3 is also implicated in the circadian system, as it is upregulated in the SCN following a nighttime light pulse (Morris et al., 1998). Lastly, glutamate is also an important neurotransmitter for conveying photic entrainment cues to the SCN (Golombek and Rosenstein, 2010), for communication between SCN hemispheres (Michel et al., 2013) and between the SCN and other brain regions (Zhang et al., 2006). As well, glutamate shows rhythmic fluctuations in the prefrontal cortex during the sleep/wake cycle (Lopez-Rodriguez et al., 2007). Group II metabotropic glutamate receptors mGLU2 and mGLU3 are encoded by the genes Grm2 and Grm3, which are expressed in the SCN (Ebling, 1996), and have various effects on sleep structure (Feinberg et al., 2002).

Additionally, in a study by Dittrich et al., mice of the 129S4 strain, which have a natural deletion mutation of Disc1, showed altered sleep regulation compared to C57BL/6N mice (Dittrich 
et al., 2017). Interestingly, introducing normal Disc1 locus from C57BL/6N mice did not rescue the phenotype. This may highlight the involvement of additional mutations in 129S4 mice in the sleep-related pathway that may or may not involve Discl.

This emphasizes that caution should be exercised when attributing causality between single mutations in mouse models and resulting phenotypes. Overall, it is possible that a gene or protein of interest involved in both schizophrenia and sleep or circadian rhythms is involved in the interaction of these factors, but in some cases, the effect could be in parallel, with no causal relationship.

\section{Circadian disturbances may affect disorder onset and severity of schizophrenia symptoms}

Negative health and behavioral consequences of circadian rhythm disruption

With the entry into a highly digital era and the high demands of the current 24-hour society, many people prioritize aligning sleep/wake times with social and work times, instead of natural circadian timing cues, such as the rising and setting of the sun (Roenneberg et al., 2019). Compelling evidence suggests that there are adverse mental and physical consequences of perturbations of our circadian biology, especially if exposure to these perturbations is chronic (Evans and Davidson, 2013). Circadian rhythm disruption has been linked to cardiovascular disease, different types of cancers, diabetes, and obesity risk (Vetter et al., 2015; Strohmaier et al., 2018; Wang et al., 2018). Chronic circadian disruption was shown to increase mortality rates in Drosophila (Pittendrigh and Minis, 1972) and aged mice (Davidson et al., 2006), to alter innate immune responses (Castanon-Cervantes et al., 2010), and to directly regulate mood-related behaviors and cognitive functions in mice (LeGates et al., 2012; Fisk et al., 2018). In a study by Karatsoreos and colleagues, researchers reported that housing mice in 20-hour LD cycles resulted 
in a number of effects such as weight gain, a reduction of dendritic length in neurons in the brain, and decreased cognitive flexibility (Karatsoreos et al., 2011).

These observations suggest that sleep and circadian disruption lead to negative health and behavioral consequences. It is largely unknown whether sleep and circadian disruptions affect schizophrenia and if so, how? As mentioned above, reports have showed that sleep disturbances can precede prodromal psychotic symptoms in patients with schizophrenia (Tan and Ang, 2001; Chouinard et al., 2004; Wulff and Joyce, 2011; Zanini et al., 2013). However, even if a causal relationship between such disturbances and the etiology of schizophrenia is suggested, the presented results are correlations. More work would be needed to demonstrate a causal relationship between circadian disruptions and schizophrenia. Below, we describe the few studies that have attempted to address such a causal link.

\section{[INSERT FIGURE 2]}

\section{Testing if circadian rhythm disruption is a risk factor for schizophrenia}

A commonly accredited hypothesis is that schizophrenia is a multifactorial disorder where numerous risk factors interact within a genetically vulnerable individual resulting in schizophrenia illness (Davis et al., 2016). Perhaps circadian rhythm disruption increases the risk for schizophrenia and interacts with other risk factors to exacerbate schizophrenia-relevant behavioral and neurobiological abnormalities (Figure 2).

Chronotype is an individual's preferred timing of sleep and activity, which is a reflection of one's endogenous circadian clock, the social environment and age-related factors (Takahashi et al., 2018; Roenneberg et al., 2019). In general, the more extreme the chronotype (i.e. extreme morning or extreme evening preference), the greater the misalignment with conventional social 
schedules (for example, work and social schedules) resulting in social jetlag (Wittmann et al., 2006). Social jetlag imposes a chronic disruption on the circadian system and late chronotypes in particular show substantial sleep debt (Roenneberg et al., 2003) and greater social jetlag than early chronotypes (Roenneberg et al., 2019). In a GWAS, Jones et al. explored the genetics of chronotype in relation to mental health disorders including schizophrenia (Jones et al., 2019). In a subset of nearly 700,000 subjects, the researchers used Mendelian randomization to infer causality between morningness (being an early chronotype) and reduced risk of schizophrenia (Jones et al., 2019). Perhaps the relationship between schizophrenia and chronotype is based on social jetlag; thus, conducting large studies on populations including individuals with schizophrenia, which would include information on chronotype and social jetlag, would be informative.

Circadian rhythm disruption as a risk factor for schizophrenia could be better studied in animal models, but such studies are scarce. To our knowledge, the only study so far that has directly tested this hypothesis is the one by Bhardwaj and colleagues (2015) using Sandy (Dysbindin-1 mutant) mice. Mice with a mutation in the Dtnbpl gene show behavioral abnormalities, including cognitive deficits, reminiscent of schizophrenia patients (Bhardwaj et al., 2009; Cox et al., 2009; Talbot, 2009). Sandy mice also have altered dopamine/D2 receptor signaling (Papaleo et al., 2012) and altered neuronal excitability. Schizophrenia-relevant behaviors of Sandy mice were tested once after exposure to an LD cycle, and then once more after LL exposure, a condition that alters and dampens circadian rhythmicity. LL exposure caused significant deficits in prepulse inhibition of acoustic startle response, hyperlocomotion and less anxiety-like behavior in Sandy mice compared to controls (Bhardwaj et al., 2015). It was hypothesized that circadian disturbances, due to LL exposure, may have exacerbated pre-existing connectivity impairments in the Sandy mice, and therefore unmasked behavioral deficits. Notably, 3 weeks of LD were sufficient to partially rescue the observed behavioral deficits (Bhardwaj et al., 2015). 
Clearly, further research is needed to evaluate if circadian disruption is a risk factor for schizophrenia. Studies should test whether exposure to circadian disruption that desynchronizes rhythms in the SCN or in other tissues, or genetic mutations that disrupt clock function, would exacerbate schizophrenia-relevant behavioral and neurobiological abnormalities.

\section{Conclusion}

If there is a prominent link between circadian rhythms and schizophrenia, then disturbances to the circadian system could affect disorder outcomes in patients. This suggests that 'at risk' and affected individuals would benefit from limited exposure to environments that promote circadian rhythm disruption. Also, restoring circadian rhythmicity could be used as an adjunctive therapy for schizophrenia. There is a clear urgency for novel and adjunctive therapies, as the current limited treatment options are insufficient to alleviate the full range of symptoms experienced by individuals with schizophrenia. The mouse model studies suggest that the biological mechanisms that contribute to sleep disruption in the context of schizophrenia may be distinct from those responsible for altered circadian entrainment and rhythmicity, such that different treatment strategies might have to be considered to address each aspect.

Here, we argue that circadian disruption is a core pathophysiological component of schizophrenia. Circadian disruption is a consistent core feature observed in most patients. Moreover, promising preliminary evidence suggests that circadian disruption may also act an interacting risk factor for schizophrenia, affecting aspects of the disorder.

We acknowledge that sleep and circadian disruptions are not specific to schizophrenia. Indeed, a number of studies have observed sleep and circadian disruptions in various neurodevelopmental, neurodegenerative, and intellectual disorders. Perhaps this speaks to sleep 
and circadian disturbances being a key psychopathological mechanism across a wide range of disorders.

The topic of sleep and circadian rhythms in schizophrenia is a burgeoning field due recent technical and methodological advances that allow this phenomenon to be studied more precisely. The majority of studies exploring the link between circadian rhythms and schizophrenia so far have mainly been correlative and descriptive in nature. There is currently a significant gap in the literature with regards to the precise mechanistic link between schizophrenia and circadian rhythms, which future research should address. Another important aspect that remains to be explored is the interaction of circadian disruption with non-genetic risk factors of schizophrenia. 


\section{Acknowledgements}

The authors thank the members of the Cermakian and Srivastava laboratories for helpful discussions. Figures were created with biorender.com.

\section{Declaration of Conflicting Interests}

The authors declare that there is no conflict of interest.

\section{Funding}

The authors disclosed receipt of the following financial support for the research, authorship, and/or publication of this article: This work was supported by grants from the Canadian Institute of Health Research [PJT-153299]; the Natural Sciences and Engineering Research Council of Canada [RGPIN-2017-04675]; and Velux Stiftung [Project 927]. TD was supported by graduate scholarships from the Schizophrenia Society of Canada Foundation, the Canadian College of Neuropsychopharmacology, and the Fonds de Recherche du Québec - Santé. 


\section{References}

Ayhan Y, McFarland R, and Pletnikov MV (2016) Animal models of gene-environment interaction in schizophrenia: A dimensional perspective. Prog Neurobiol 136:1-27.

Barnes MR, Huxley-Jones J, Maycox PR, Lennon M, Thornber A, Kelly F, Bates S, Taylor A, Reid J, Jones N, Schroeder J, Scorer CA, Davies C, Hagan JJ, Kew JN, Angelinetta C, Akbar T, Hirsch S, Mortimer AM, Barnes TR, and de Belleroche J (2011) Transcription and pathway analysis of the superior temporal cortex and anterior prefrontal cortex in schizophrenia. J Neurosci Res 89:1218-1227.

Bhardwaj SK, Baharnoori M, Sharif-Askari B, Kamath A, Williams S, and Srivastava LK (2009) Behavioral characterization of dysbindin-1 deficient sandy mice. Behav Brain Res 197:435441.

Bhardwaj SK, Stojkovic K, Kiessling S, Srivastava LK, and Cermakian N (2015) Constant light uncovers behavioral effects of a mutation in the schizophrenia risk gene Dtnbp1 in mice. Behav Brain Res 284:58-68.

Borbely AA (2009) Refining sleep homeostasis in the two-process model. J Sleep Res 18:1-2.

Bozon B, Davis S, and Laroche S (2002) Regulated transcription of the immediate-early gene Zif268: mechanisms and gene dosage-dependent function in synaptic plasticity and memory formation. Hippocampus 12:570-577.

Bozon B, Davis S, and Laroche S (2003) A requirement for the immediate early gene zif268 in reconsolidation of recognition memory after retrieval. Neuron 40:695-701.

Bromundt V, Koster M, Georgiev-Kill A, Opwis K, Wirz-Justice A, Stoppe G, and Cajochen C (2011) Sleep-wake cycles and cognitive functioning in schizophrenia. Br J Psychiatry 198:269-276. 
Castanon-Cervantes O, Wu M, Ehlen JC, Paul K, Gamble KL, Johnson RL, Besing RC, Menaker M, Gewirtz AT, and Davidson AJ (2010) Dysregulation of inflammatory responses by chronic circadian disruption. J Immunol 185:5796-5805.

Chen X, Ma W, Zhang S, Paluch J, Guo W, and Dickman DK (2017) The BLOC-1 Subunit Pallidin Facilitates Activity-Dependent Synaptic Vesicle Recycling. eNeuro 4.

Chiu VW, Ree M, Janca A, Iyyalol R, Dragovic M, and Waters F (2018) Sleep profiles and CBTI response in schizophrenia and related psychoses. Psychiatry Res 268:279-287.

Chouinard S, Poulin J, Stip E, and Godbout R (2004) Sleep in untreated patients with schizophrenia: a meta-analysis. Schizophr Bull 30:957-967.

Chubb JE, Bradshaw NJ, Soares DC, Porteous DJ, and Millar JK (2008) The DISC locus in psychiatric illness. Mol Psychiatry 13:36-64.

Cohrs S (2008) Sleep disturbances in patients with schizophrenia : impact and effect of antipsychotics. CNS Drugs 22:939-962.

Consortium SWGotPG (2014) Biological insights from 108 schizophrenia-associated genetic loci. Nature 511:421-427.

Cox MM, Tucker AM, Tang J, Talbot K, Richer DC, Yeh L, and Arnold SE (2009) Neurobehavioral abnormalities in the dysbindin-1 mutant, sandy, on a C57BL/6J genetic background. Genes Brain Behav 8:390-397.

Davidson AJ, Sellix MT, Daniel J, Yamazaki S, Menaker M, and Block GD (2006) Chronic jetlag increases mortality in aged mice. Curr Biol 16:R914-916.

Davis J, Eyre H, Jacka FN, Dodd S, Dean O, McEwen S, Debnath M, McGrath J, Maes M, Amminger P, McGorry PD, Pantelis C, and Berk M (2016) A review of vulnerability and risks for schizophrenia: Beyond the two hit hypothesis. Neurosci Biobehav Rev 65:185194. 
de Sena Cortabitarte A, Degenhardt F, Strohmaier J, Lang M, Weiss B, Roeth R, Giegling I, Heilmann-Heimbach S, Hofmann A, Rujescu D, Fischer C, Rietschel M, Nothen MM, Rappold GA, and Berkel S (2017) Investigation of SHANK3 in schizophrenia. Am J Med Genet B Neuropsychiatr Genet 174:390-398.

Dibner C, Schibler U, and Albrecht U (2010) The mammalian circadian timing system: organization and coordination of central and peripheral clocks. Annu Rev Physiol 72:517549.

Dickman DK, and Davis GW (2009) The schizophrenia susceptibility gene dysbindin controls synaptic homeostasis. Science 326:1127-1130.

Dittrich L, Petese A, and Jackson WS (2017) The natural Disc1-deletion present in several inbred mouse strains does not affect sleep. Sci Rep 7:5665.

Ebling FJ (1996) The role of glutamate in the photic regulation of the suprachiasmatic nucleus. Prog Neurobiol 50:109-132.

Egan MF, Straub RE, Goldberg TE, Yakub I, Callicott JH, Hariri AR, Mattay VS, Bertolino A, Hyde TM, Shannon-Weickert C, Akil M, Crook J, Vakkalanka RK, Balkissoon R, Gibbs RA, Kleinman JE, and Weinberger DR (2004) Variation in GRM3 affects cognition, prefrontal glutamate, and risk for schizophrenia. Proc Natl Acad Sci U S A 101:1260412609.

Evans JA, and Davidson AJ (2013) Health consequences of circadian disruption in humans and animal models. Prog Mol Biol Transl Sci 119:283-323.

Falcon-Perez JM, Starcevic M, Gautam R, and Dell'Angelica EC (2002) BLOC-1, a novel complex containing the pallidin and muted proteins involved in the biogenesis of melanosomes and platelet-dense granules. J Biol Chem 277:28191-28199. 
Fanous AH, Zhao Z, van den Oord E, Maher BS, Thiselton DL, Bergen SE, Wormley B, Bigdeli T, Amdur RL, O'Neill FA, Walsh D, Kendler KS, and Riley BP (2010) Association study of SNAP25 and schizophrenia in Irish family and case-control samples. Am J Med Genet B Neuropsychiatr Genet 153B:663-674.

Fatemi SH, Earle JA, Stary JM, Lee S, and Sedgewick J (2001) Altered levels of the synaptosomal associated protein SNAP-25 in hippocampus of subjects with mood disorders and schizophrenia. Neuroreport 12:3257-3262.

Feinberg I, Campbell IG, Schoepp DD, and Anderson K (2002) The selective group mGlu2/3 receptor agonist LY379268 suppresses REM sleep and fast EEG in the rat. Pharmacol Biochem Behav 73:467-474.

Feng YQ, Zhou ZY, He X, Wang H, Guo XL, Hao CJ, Guo Y, Zhen XC, and Li W (2008) Dysbindin deficiency in sandy mice causes reduction of snapin and displays behaviors related to schizophrenia. Schizophr Res 106:218-228.

Fisk AS, Tam SKE, Brown LA, Vyazovskiy VV, Bannerman DM, and Peirson SN (2018) Light and Cognition: Roles for Circadian Rhythms, Sleep, and Arousal. Front Neurol 9:56.

Frankle WG, Lerma J, and Laruelle M (2003) The synaptic hypothesis of schizophrenia. Neuron $39: 205-216$.

Freeman D, Sheaves B, Goodwin GM, Yu LM, Nickless A, Harrison PJ, Emsley R, Luik AI, Foster RG, Wadekar V, Hinds C, Gumley A, Jones R, Lightman S, Jones S, Bentall R, Kinderman P, Rowse G, Brugha T, Blagrove M, Gregory AM, Fleming L, Walklet E, Glazebrook C, Davies EB, Hollis C, Haddock G, John B, Coulson M, Fowler D, Pugh K, Cape J, Moseley P, Brown G, Hughes C, Obonsawin M, Coker S, Watkins E, Schwannauer M, MacMahon K, Siriwardena AN, and Espie CA (2017) The effects of improving sleep on mental health 
(OASIS): a randomised controlled trial with mediation analysis. Lancet Psychiatry 4:749758.

Freeman D, Taylor KM, Molodynski A, and Waite F (2019) Treatable clinical intervention targets for patients with schizophrenia. Schizophr Res 211:44-50.

Garay RP, Bourin M, de Paillette E, Samalin L, Hameg A, and Llorca PM (2016) Potential serotonergic agents for the treatment of schizophrenia. Expert Opin Investig Drugs 25:159170.

Gauthier J, Champagne N, Lafreniere RG, Xiong L, Spiegelman D, Brustein E, Lapointe M, Peng H, Cote M, Noreau A, Hamdan FF, Addington AM, Rapoport JL, Delisi LE, Krebs MO, Joober R, Fathalli F, Mouaffak F, Haghighi AP, Neri C, Dube MP, Samuels ME, Marineau C, Stone EA, Awadalla P, Barker PA, Carbonetto S, Drapeau P, Rouleau GA, and Team SD (2010) De novo mutations in the gene encoding the synaptic scaffolding protein SHANK3 in patients ascertained for schizophrenia. Proc Natl Acad Sci U S A 107:78637868.

Ghiani CA, and Dell'Angelica EC (2011) Dysbindin-containing complexes and their proposed functions in brain: from zero to (too) many in a decade. ASN Neuro 3.

Golombek DA, and Rosenstein RE (2010) Physiology of circadian entrainment. Physiol Rev 90:1063-1102.

Gronli J, Clegern WC, Schmidt MA, Nemri RS, Rempe MJ, Gallitano AL, and Wisor JP (2016) Sleep Homeostatic and Waking Behavioral Phenotypes in Egr3-Deficient Mice Associated with Serotonin Receptor 5-HT2 Deficits. Sleep 39:2189-2199.

Harrison PJ, Lyon L, Sartorius LJ, Burnet PW, and Lane TA (2008) The group II metabotropic glutamate receptor 3 (mGluR3, mGlu3, GRM3): expression, function and involvement in schizophrenia. J Psychopharmacol 22:308-322. 
Harrison PJ, and Weinberger DR (2005) Schizophrenia genes, gene expression, and neuropathology: on the matter of their convergence. Mol Psychiatry 10:40-68; image 45.

Hartwig C, Monis WJ, Chen X, Dickman DK, Pazour GJ, and Faundez V (2018) Neurodevelopmental disease mechanisms, primary cilia, and endosomes converge on the BLOC-1 and BORC complexes. Dev Neurobiol 78:311-330.

Hastings MH, Maywood ES, and Brancaccio M (2018) Generation of circadian rhythms in the suprachiasmatic nucleus. Nat Rev Neurosci 19:453-469.

Hennah W, Varilo T, Kestila M, Paunio T, Arajarvi R, Haukka J, Parker A, Martin R, Levitzky S, Partonen T, Meyer J, Lonnqvist J, Peltonen L, and Ekelund J (2003) Haplotype transmission analysis provides evidence of association for DISC1 to schizophrenia and suggests sex-dependent effects. Hum Mol Genet 12:3151-3159.

Huentelman MJ, Muppana L, Corneveaux JJ, Dinu V, Pruzin JJ, Reiman R, Borish CN, De Both M, Ahmed A, Todorov A, Cloninger CR, Zhang R, Ma J, and Gallitano AL (2015) Association of SNPs in EGR3 and ARC with Schizophrenia Supports a Biological Pathway for Schizophrenia Risk. PLoS One 10:e0135076.

Hurlemann R, Boy C, Meyer PT, Scherk H, Wagner M, Herzog H, Coenen HH, Vogeley K, Falkai P, Zilles K, Maier W, and Bauer A (2005) Decreased prefrontal 5-HT2A receptor binding in subjects at enhanced risk for schizophrenia. Anat Embryol (Berl) 210:519-523.

Hwang DK, Nam M, and Lee YG (2019) The effect of cognitive behavioral therapy for insomnia in schizophrenia patients with sleep Disturbance: A non-randomized, assessor-blind trial. Psychiatry Res 274:182-188.

Ingiosi AM, Schoch H, Wintler T, Singletary KG, Righelli D, Roser LG, Medina E, Risso D, Frank MG, and Peixoto L (2019) Shank3 modulates sleep and expression of circadian transcription factors. Elife 8 . 
Jaaro-Peled H, Altimus C, LeGates T, Cash-Padgett T, Zoubovsky S, Hikida T, Ishizuka K, Hattar S, Mongrain V, and Sawa A (2016) Abnormal wake/sleep pattern in a novel gain-offunction model of DISC1. Neurosci Res 112:63-69.

Jablensky A (2000) Epidemiology of schizophrenia: the global burden of disease and disability. Eur Arch Psychiatry Clin Neurosci 250:274-285.

Jablensky A (2010) The diagnostic concept of schizophrenia: its history, evolution, and future prospects. Dialogues Clin Neurosci 12:271-287.

Jagannath A, Peirson SN, and Foster RG (2013) Sleep and circadian rhythm disruption in neuropsychiatric illness. Curr Opin Neurobiol 23:888-894.

Jeans AF, Oliver PL, Johnson R, Capogna M, Vikman J, Molnar Z, Babbs A, Partridge CJ, Salehi A, Bengtsson M, Eliasson L, Rorsman P, and Davies KE (2007) A dominant mutation in Snap25 causes impaired vesicle trafficking, sensorimotor gating, and ataxia in the blinddrunk mouse. Proc Natl Acad Sci U S A 104:2431-2436.

Johansson AS, Owe-Larsson B, Hetta J, and Lundkvist GB (2016) Altered circadian clock gene expression in patients with schizophrenia. Schizophr Res 174:17-23.

Jones SE, Lane JM, Wood AR, van Hees VT, Tyrrell J, Beaumont RN, Jeffries AR, Dashti HS, Hillsdon M, Ruth KS, Tuke MA, Yaghootkar H, Sharp SA, Jie Y, Thompson WD, Harrison JW, Dawes A, Byrne EM, Tiemeier H, Allebrandt KV, Bowden J, Ray DW, Freathy RM, Murray A, Mazzotti DR, Gehrman PR, Lawlor DA, Frayling TM, Rutter MK, Hinds DA, Saxena R, and Weedon MN (2019) Genome-wide association analyses of chronotype in 697,828 individuals provides insights into circadian rhythms. Nat Commun 10:343.

Kahn RS, Sommer IE, Murray RM, Meyer-Lindenberg A, Weinberger DR, Cannon TD, O'Donovan M, Correll CU, Kane JM, van Os J, and Insel TR (2015) Schizophrenia. Nat Rev Dis Primers 1:15067. 
Karatsoreos IN, Bhagat S, Bloss EB, Morrison JH, and McEwen BS (2011) Disruption of circadian clocks has ramifications for metabolism, brain, and behavior. Proc Natl Acad Sci U S A 108:1657-1662.

Kaskie RE, Graziano B, and Ferrarelli F (2017) Schizophrenia and sleep disorders: links, risks, and management challenges. Nat Sci Sleep 9:227-239.

Korenic SA, Klingaman EA, Wickwire EM, Gaston FE, Chen H, Wijtenburg SA, and Rowland LM (2019) Sleep quality is related to brain glutamate and symptom severity in schizophrenia. J Psychiatr Res 120:14-20.

Kraepelin E, Barclay RM, and Robertson GM (1919) Dementia praecox and paraphrenia. Edinburgh: E \&S Livingstone.

Kumamoto N, Matsuzaki S, Inoue K, Hattori T, Shimizu S, Hashimoto R, Yamatodani A, Katayama T, and Tohyama M (2006) Hyperactivation of midbrain dopaminergic system in schizophrenia could be attributed to the down-regulation of dysbindin. Biochem Biophys Res Commun 345:904-909.

Laskemoen JF, Simonsen C, Buchmann C, Barrett EA, Bjella T, Lagerberg TV, Vedal TJ, Andreassen OA, Melle I, and Aas M (2019) Sleep disturbances in schizophrenia spectrum and bipolar disorders - a transdiagnostic perspective. Compr Psychiatry 91:6-12.

Lee FY, Wang HB, Hitchcock ON, Loh DH, Whittaker DS, Kim YS, Aiken A, Kokikian C, Dell'Angelica EC, Colwell CS, and Ghiani CA (2018) Sleep/Wake Disruption in a Mouse Model of BLOC-1 Deficiency. Front Neurosci 12:759.

LeGates TA, Altimus CM, Wang H, Lee HK, Yang S, Zhao H, Kirkwood A, Weber ET, and Hattar S (2012) Aberrant light directly impairs mood and learning through melanopsin-expressing neurons. Nature 491:594-598. 
Li L, Yun SH, Keblesh J, Trommer BL, Xiong H, Radulovic J, and Tourtellotte WG (2007) Egr3, a synaptic activity regulated transcription factor that is essential for learning and memory. Mol Cell Neurosci 35:76-88.

Logan RW, and McClung CA (2019) Rhythms of life: circadian disruption and brain disorders across the lifespan. Nat Rev Neurosci 20:49-65.

Lopez-Rodriguez F, Medina-Ceja L, Wilson CL, Jhung D, and Morales-Villagran A (2007) Changes in extracellular glutamate levels in rat orbitofrontal cortex during sleep and wakefulness. Arch Med Res 38:52-55.

Lunsford-Avery JR, Goncalves B, Brietzke E, Bressan RA, Gadelha A, Auerbach RP, and Mittal VA (2017) Adolescents at clinical-high risk for psychosis: Circadian rhythm disturbances predict worsened prognosis at 1-year follow-up. Schizophr Res 189:37-42.

Luthringer R, Staner L, Noel N, Muzet M, Gassmann-Mayer C, Talluri K, Cleton A, Eerdekens M, Battisti WP, and Palumbo JM (2007) A double-blind, placebo-controlled, randomized study evaluating the effect of paliperidone extended-release tablets on sleep architecture in patients with schizophrenia. Int Clin Psychopharmacol 22:299-308.

Maple AM, Rowe RK, Lifshitz J, Fernandez F, and Gallitano AL (2018) Influence of Schizophrenia-Associated Gene Egr3 on Sleep Behavior and Circadian Rhythms in Mice. J Biol Rhythms 33:662-670.

Maple AM, Zhao X, Elizalde DI, McBride AK, and Gallitano AL (2015) Htr2a Expression Responds Rapidly to Environmental Stimuli in an Egr3-Dependent Manner. ACS Chem Neurosci 6:1137-1142.

Martin J, Jeste DV, Caliguiri MP, Patterson T, Heaton R, and Ancoli-Israel S (2001) Actigraphic estimates of circadian rhythms and sleep/wake in older schizophrenia patients. Schizophr Res 47:77-86. 
Martin JL, Jeste DV, and Ancoli-Israel S (2005) Older schizophrenia patients have more disrupted sleep and circadian rhythms than age-matched comparison subjects. J Psychiatr Res 39:251-259.

McGrath J, Saha S, Chant D, and Welham J (2008) Schizophrenia: a concise overview of incidence, prevalence, and mortality. Epidemiol Rev 30:67-76.

Mexal S, Frank M, Berger R, Adams CE, Ross RG, Freedman R, and Leonard S (2005) Differential modulation of gene expression in the NMDA postsynaptic density of schizophrenic and control smokers. Brain Res Mol Brain Res 139:317-332.

Meyer N, Faulkner SM, McCutcheon RA, Pillinger T, Dijk DJ, and MacCabe JH (2020) Sleep and Circadian Rhythm Disturbance in Remitted Schizophrenia and Bipolar Disorder: A Systematic Review and Meta-analysis. Schizophr Bull.

Michel S, Marek R, Vanderleest HT, Vansteensel MJ, Schwartz WJ, Colwell CS, and Meijer JH (2013) Mechanism of bilateral communication in the suprachiasmatic nucleus. Eur J Neurosci 37:964-971.

Millar JK, Wilson-Annan JC, Anderson S, Christie S, Taylor MS, Semple CA, Devon RS, St Clair DM, Muir WJ, Blackwood DH, and Porteous DJ (2000) Disruption of two novel genes by a translocation co-segregating with schizophrenia. Hum Mol Genet 9:1415-1423.

Mishra A, Maiti R, Mishra BR, Jena M, Nath S, and Sahu P (2020) Effect of add-on ramelteon therapy on sleep and circadian rhythm disruption in patients with schizophrenia: A randomized controlled trial. Eur Neuropsychopharmacol 31:109-118.

Miyamoto S, Duncan GE, Marx CE, and Lieberman JA (2005) Treatments for schizophrenia: a critical review of pharmacology and mechanisms of action of antipsychotic drugs. Mol Psychiatry 10:79-104. 
Mohrmann R, de Wit H, Verhage M, Neher E, and Sorensen JB (2010) Fast vesicle fusion in living cells requires at least three SNARE complexes. Science 330:502-505.

Monti JM, BaHammam AS, Pandi-Perumal SR, Bromundt V, Spence DW, Cardinali DP, and Brown GM (2013) Sleep and circadian rhythm dysregulation in schizophrenia. Prog Neuropsychopharmacol Biol Psychiatry 43:209-216.

Morris ME, Viswanathan N, Kuhlman S, Davis FC, and Weitz CJ (1998) A screen for genes induced in the suprachiasmatic nucleus by light. Science 279:1544-1547.

Mullin AP, Gokhale A, Larimore J, and Faundez V (2011) Cell biology of the BLOC-1 complex subunit dysbindin, a schizophrenia susceptibility gene. Mol Neurobiol 44:53-64.

Ohta H, Yamazaki S, and McMahon DG (2005) Constant light desynchronizes mammalian clock neurons. Nat Neurosci 8:267-269.

Oliver PL, Sobczyk MV, Maywood ES, Edwards B, Lee S, Livieratos A, Oster H, Butler R, Godinho SI, Wulff K, Peirson SN, Fisher SP, Chesham JE, Smith JW, Hastings MH, Davies KE, and Foster RG (2012) Disrupted circadian rhythms in a mouse model of schizophrenia. Curr Biol 22:314-319.

Panda S, Antoch MP, Miller BH, Su AI, Schook AB, Straume M, Schultz PG, Kay SA, Takahashi JS, and Hogenesch JB (2002) Coordinated transcription of key pathways in the mouse by the circadian clock. Cell 109:307-320.

Papaleo F, Yang F, Garcia S, Chen J, Lu B, Crawley JN, and Weinberger DR (2012) Dysbindin-1 modulates prefrontal cortical activity and schizophrenia-like behaviors via dopamine/D2 pathways. Mol Psychiatry 17:85-98.

Pittendrigh CS, and Minis DH (1972) Circadian systems: longevity as a function of circadian resonance in Drosophila melanogaster. Proc Natl Acad Sci U S A 69:1537-1539. 
Poe SL, Brucato G, Bruno N, Arndt LY, Ben-David S, Gill KE, Colibazzi T, Kantrowitz JT, Corcoran CM, and Girgis RR (2017) Sleep disturbances in individuals at clinical high risk for psychosis. Psychiatry Res 249:240-243.

Porteous DJ, Millar JK, Brandon NJ, and Sawa A (2011) DISC1 at 10: connecting psychiatric genetics and neuroscience. Trends Mol Med 17:699-706.

Pritchett D, Jagannath A, Brown LA, Tam SK, Hasan S, Gatti S, Harrison PJ, Bannerman DM, Foster RG, and Peirson SN (2015) Deletion of Metabotropic Glutamate Receptors 2 and 3 (mGlu2 \& mGlu3) in Mice Disrupts Sleep and Wheel-Running Activity, and Increases the Sensitivity of the Circadian System to Light. PLoS One 10:e0125523.

Pritchett D, Wulff K, Oliver PL, Bannerman DM, Davies KE, Harrison PJ, Peirson SN, and Foster RG (2012) Evaluating the links between schizophrenia and sleep and circadian rhythm disruption. J Neural Transm (Vienna) 119:1061-1075.

Reeve S, Sheaves B, and Freeman D (2015) The role of sleep dysfunction in the occurrence of delusions and hallucinations: A systematic review. Clin Psychol Rev 42:96-115.

Roenneberg T, Pilz LK, Zerbini G, and Winnebeck EC (2019) Chronotype and Social Jetlag: A (Self-) Critical Review. Biology (Basel) 8.

Roenneberg T, Wirz-Justice A, and Merrow M (2003) Life between clocks: daily temporal patterns of human chronotypes. J Biol Rhythms 18:80-90.

Ryder PV, and Faundez V (2009) Schizophrenia: the "BLOC" may be in the endosomes. Sci Signal 2:pe66.

Saper CB, Scammell TE, and Lu J (2005) Hypothalamic regulation of sleep and circadian rhythms. Nature 437:1257-1263.

Sawamura N, Ando T, Maruyama Y, Fujimuro M, Mochizuki H, Honjo K, Shimoda M, Toda H, Sawamura-Yamamoto T, Makuch LA, Hayashi A, Ishizuka K, Cascella NG, Kamiya A, 
Ishida N, Tomoda T, Hai T, Furukubo-Tokunaga K, and Sawa A (2008) Nuclear DISC1 regulates CRE-mediated gene transcription and sleep homeostasis in the fruit fly. Mol Psychiatry 13:1138-1148, 1069.

Schwab SG, Knapp M, Mondabon S, Hallmayer J, Borrmann-Hassenbach M, Albus M, Lerer B, Rietschel M, Trixler M, Maier W, and Wildenauer DB (2003) Support for association of schizophrenia with genetic variation in the 6p22.3 gene, dysbindin, in sib-pair families with linkage and in an additional sample of triad families. Am J Hum Genet 72:185-190.

Seney ML, Cahill K, Enwright JF, 3rd, Logan RW, Huo Z, Zong W, Tseng G, and McClung CA (2019) Diurnal rhythms in gene expression in the prefrontal cortex in schizophrenia. Nat Commun 10:3355.

Sheaves B, Freeman D, Isham L, McInerney J, Nickless A, Yu LM, Rek S, Bradley J, Reeve S, Attard C, Espie CA, Foster R, Wirz-Justice A, Chadwick E, and Barrera A (2018) Stabilising sleep for patients admitted at acute crisis to a psychiatric hospital (OWLS): an assessor-blind pilot randomised controlled trial. Psychol Med 48:1694-1704.

Sheng M, and Kim E (2000) The Shank family of scaffold proteins. J Cell Sci 113 ( Pt 11):18511856.

Stilo SA, and Murray RM (2019) Non-Genetic Factors in Schizophrenia. Curr Psychiatry Rep 21:100.

Straub RE, Jiang Y, MacLean CJ, Ma Y, Webb BT, Myakishev MV, Harris-Kerr C, Wormley B, Sadek H, Kadambi B, Cesare AJ, Gibberman A, Wang X, O'Neill FA, Walsh D, and Kendler KS (2002) Genetic variation in the 6p22.3 gene DTNBP1, the human ortholog of the mouse dysbindin gene, is associated with schizophrenia. Am J Hum Genet 71:337-348. 
Strohmaier S, Devore EE, Zhang Y, and Schernhammer ES (2018) A Review of Data of Findings on Night Shift Work and the Development of DM and CVD Events: a Synthesis of the Proposed Molecular Mechanisms. Curr Diab Rep 18:132.

Takahashi M, Tahara Y, Tsubosaka M, Fukazawa M, Ozaki M, Iwakami T, Nakaoka T, and Shibata S (2018) Chronotype and social jetlag influence human circadian clock gene expression. Sci Rep 8:10152.

Talbot K (2009) The sandy (sdy) mouse: a dysbindin-1 mutant relevant to schizophrenia research. Prog Brain Res 179:87-94.

Talbot K, Eidem WL, Tinsley CL, Benson MA, Thompson EW, Smith RJ, Hahn CG, Siegel SJ, Trojanowski JQ, Gur RE, Blake DJ, and Arnold SE (2004) Dysbindin-1 is reduced in intrinsic, glutamatergic terminals of the hippocampal formation in schizophrenia. J Clin Invest 113:1353-1363.

Tan HY, and Ang YG (2001) First-episode psychosis in the military: a comparative study of prodromal symptoms. Aust N Z J Psychiatry 35:512-519.

Tandon R, Gaebel W, Barch DM, Bustillo J, Gur RE, Heckers S, Malaspina D, Owen MJ, Schultz S, Tsuang M, Van Os J, and Carpenter W (2013) Definition and description of schizophrenia in the DSM-5. Schizophr Res 150:3-10.

Tang J, LeGros RP, Louneva N, Yeh L, Cohen JW, Hahn CG, Blake DJ, Arnold SE, and Talbot K (2009) Dysbindin-1 in dorsolateral prefrontal cortex of schizophrenia cases is reduced in an isoform-specific manner unrelated to dysbindin-1 mRNA expression. Hum Mol Genet 18:3851-3863.

Tsai G, and Coyle JT (2002) Glutamatergic mechanisms in schizophrenia. Annu Rev Pharmacol Toxicol 42:165-179. 
van Os J, Rutten BP, and Poulton R (2008) Gene-environment interactions in schizophrenia: review of epidemiological findings and future directions. Schizophr Bull 34:1066-1082.

Vetter C, Devore EE, Ramin CA, Speizer FE, Willett WC, and Schernhammer ES (2015) Mismatch of Sleep and Work Timing and Risk of Type 2 Diabetes. Diabetes Care 38:1707-1713.

Waite F, Sheaves B, Isham L, Reeve S, and Freeman D (2019) Sleep and schizophrenia: From epiphenomenon to treatable causal target. Schizophr Res.

Wang D, Ruan W, Chen Z, Peng Y, and Li W (2018) Shift work and risk of cardiovascular disease morbidity and mortality: A dose-response meta-analysis of cohort studies. Eur J Prev Cardiol 25:1293-1302.

Weickert CS, Rothmond DA, Hyde TM, Kleinman JE, and Straub RE (2008) Reduced DTNBP1 (dysbindin-1) mRNA in the hippocampal formation of schizophrenia patients. Schizophr Res 98:105-110.

Weickert CS, Straub RE, McClintock BW, Matsumoto M, Hashimoto R, Hyde TM, Herman MM, Weinberger DR, and Kleinman JE (2004) Human dysbindin (DTNBP1) gene expression in normal brain and in schizophrenic prefrontal cortex and midbrain. Arch Gen Psychiatry 61:544-555.

Wittmann M, Dinich J, Merrow M, and Roenneberg T (2006) Social jetlag: misalignment of biological and social time. Chronobiol Int 23:497-509.

Wulff K, Dijk DJ, Middleton B, Foster RG, and Joyce EM (2012) Sleep and circadian rhythm disruption in schizophrenia. Br J Psychiatry 200:308-316.

Wulff K, Gatti S, Wettstein JG, and Foster RG (2010) Sleep and circadian rhythm disruption in psychiatric and neurodegenerative disease. Nat Rev Neurosci 11:589-599.

Wulff K, and Joyce E (2011) Circadian rhythms and cognition in schizophrenia. Br J Psychiatry 198:250-252. 
Yamada K, Gerber DJ, Iwayama Y, Ohnishi T, Ohba H, Toyota T, Aruga J, Minabe Y, Tonegawa S, and Yoshikawa T (2007) Genetic analysis of the calcineurin pathway identifies members of the EGR gene family, specifically EGR3, as potential susceptibility candidates in schizophrenia. Proc Natl Acad Sci U S A 104:2815-2820.

Zanini M, Castro J, Coelho FM, Bittencourt L, Bressan RA, Tufik S, and Brietzke E (2013) Do sleep abnormalities and misaligned sleep/circadian rhythm patterns represent early clinical characteristics for developing psychosis in high risk populations? Neurosci Biobehav Rev $37: 2631-2637$.

Zhang L, Kolaj M, and Renaud LP (2006) Suprachiasmatic nucleus communicates with anterior thalamic paraventricular nucleus neurons via rapid glutamatergic and gabaergic neurotransmission: state-dependent response patterns observed in vitro. Neuroscience $141: 2059-2066$.

Zhang R, Lu S, Meng L, Min Z, Tian J, Valenzuela RK, Guo T, Tian L, Zhao W, and Ma J (2012) Genetic evidence for the association between the early growth response 3 (EGR3) gene and schizophrenia. PLoS One 7:e30237. 


\section{Figure legends}

Figure 1. Sleep, and circadian rhythm disturbances are comorbid with schizophrenia in human patients and related animal models. There is evidence to suggest that sleep and circadian rhythm disturbances constitute a fundamental component of schizophrenia, which we have reviewed in both human studies and in animal models that contain genetic mutations related to schizophrenia. Overall, most studies suggest disrupted rhythms in various tissues and assays in schizophrenia patients and related animal models. This disruption is usually seen as loss of circadian rhythmicity, fragmented rhythms, a decreased amplitude (A), and/or irregularity of rhythms.

Figure 2. Circadian disruption is proposed to interact with other schizophrenia risk factors to promote schizophrenia-relevant behavioral and neurobiological abnormalities. Disrupted photic input hits light-sensing retinal ganglion cells which relay the signals to the SCN. We hypothesize that because of the link between circadian rhythms and schizophrenia, disturbances to the circadian system can affect disorder outcomes and symptom severity in patients. This suggests that 'vulnerable' individuals would benefit from limiting exposure to environments that can disturb circadian rhythms, and that restoring circadian rhythmicity could be used as an adjunctive therapy for schizophrenia. 
Table 1. Overview of mouse models related to schizophrenia and their known sleep and circadian phenotypes

\begin{tabular}{|c|c|c|c|c|c|c|}
\hline \multicolumn{3}{|c|}{ Gene or Protein of Interest } & \multicolumn{4}{|c|}{ Details of Corresponding Animal Models } \\
\hline Name & Description & Link to Schizophrenia & Animal Model & Sleep Phenotype & $\begin{array}{l}\text { Circadian } \\
\text { Phenotype }\end{array}$ & Reference \\
\hline \multirow{3}{*}{$\begin{array}{l}\text { Disrupted-in- } \\
\text { schizophrenia } 1 \\
\text { (DISC1) }\end{array}$} & \multirow{3}{*}{$\begin{array}{l}\text { DISC1 encodes an } \\
\text { intracellular scaffold } \\
\text { protein, with a likely } \\
\text { role in neurosignaling } \\
\text { and neurodevelopment } \\
\text { (Porteous et al., 2011) }\end{array}$} & \multirow{3}{*}{$\begin{array}{l}\text { Gene linkage and gene } \\
\text { association studies in } \\
\text { diverse populations } \\
\text { (Millar et al., 2000; } \\
\text { Hennah et al., 2003; } \\
\text { Chubb et al., 2008) }\end{array}$} & $\begin{array}{c}\text { Drosophila, } \\
\text { which natively } \\
\text { lack a Discl } \\
\text { gene, } \\
\text { overexpressing } \\
\text { human DISC1 } \\
\end{array}$ & $\begin{array}{c}\uparrow \text { Sleep time } \\
\uparrow \text { Sleep bout } \\
\text { duration }\end{array}$ & Not tested & $\begin{array}{c}\text { (Sawamura et al., } \\
\text { 2008) }\end{array}$ \\
\hline & & & $\begin{array}{c}\text { Discl transgenic } \\
\text { mice that express } \\
\text { both mouse } \\
\text { Discl and } \\
\text { overexpress } \\
\text { wildtype human } \\
\text { DISCl }\end{array}$ & $\begin{array}{c}\uparrow \text { Wakefulness } \\
\downarrow \text { Sleep time } \\
\downarrow \text { Duration in } \\
\text { NREM } \\
\downarrow \text { Duration in REM } \\
\text { (between ZT2-9) } \\
\text { Tendency for } \\
\downarrow \text { rebound of delta } \\
\text { activity following } \\
\text { 2-hour sleep } \\
\text { deprivation }\end{array}$ & $\begin{array}{l}\downarrow \text { Dark (active) } \\
\text { phase activity } \\
\text { under LD } \\
\text { No change in } \\
\text { period in DD or in } \\
\text { phase shift after a } \\
\text { light pulse }\end{array}$ & $\begin{array}{l}\text { (Jaaro-Peled et } \\
\text { al., 2016) }\end{array}$ \\
\hline & & & $\begin{array}{l}\text { 129S4 mice, } \\
\text { which have a } \\
\text { natural deletion } \\
\text { mutation of } \\
\text { Discl }\end{array}$ & $\begin{array}{l}\text { Altered sleep } \\
\text { regulation } \\
\text { compared to } \\
\text { C57BL/6N mice; } \\
\text { introducing Disc1 } \\
\text { locus from } \\
\text { C57BL/6N does } \\
\text { not rescue the } \\
\text { phenotype }\end{array}$ & Not tested & $\begin{array}{c}\text { (Dittrich et al., } \\
\text { 2017) }\end{array}$ \\
\hline
\end{tabular}




\begin{tabular}{|c|c|c|c|c|c|c|}
\hline $\begin{array}{l}\text { Early growth } \\
\text { response } 3 \\
\text { (Egr3) }\end{array}$ & $\begin{array}{l}\text { Egr3 gene encodes a } \\
\text { transcription factor that } \\
\text { plays a role in synaptic } \\
\text { plasticity, learning and } \\
\text { memory processes } \\
\text { (Bozon et al., 2002; } \\
\text { Bozon et al., 2003; Li } \\
\text { et al., 2007; Barnes et } \\
\text { al., 2011) }\end{array}$ & $\begin{array}{c}\text { EGR3 is regulated } \\
\text { downstream of a } \\
\text { cascade of genes } \\
\text { associated with } \\
\text { schizophrenia risk and } \\
\text { EGR3 was linked to } \\
\text { schizophrenia in } \\
\text { genetic association and } \\
\text { gene expression studies } \\
\text { (Mexal et al., 2005; } \\
\text { Yamada et al., 2007; } \\
\text { Zhang et al., 2012; } \\
\text { Huentelman et al., } \\
\text { 2015) }\end{array}$ & $\begin{array}{c}\text { Egr3 -/- mice } \\
\text { have a full body } \\
\text { knockout of } \\
\text { Egr3 }\end{array}$ & $\downarrow$ Total sleep time & $\begin{array}{c}\uparrow \text { Amplitude and } \\
\uparrow A l p h a \text { under } \\
\text { LD/DD/LL }\end{array}$ & $\begin{array}{l}\text { (Maple et al., } \\
\text { 2018) }\end{array}$ \\
\hline $\begin{array}{c}\text { Group II } \\
\text { metabotropic } \\
\text { glutamate } \\
\text { receptors mGlu2 } \\
\text { and } m \text { Glu3 } \\
(\text { Grm } 2 / 3)\end{array}$ & $\begin{array}{l}\text { Group II metabotropic } \\
\text { glutamate receptors } \\
\text { mGLU2 and mGLU3, } \\
\text { encoded by the genes } \\
\text { Grm } 2 \text { and } G r m 3 \text {, are } \\
\text { presynaptic inhibitory } \\
\text { autoreceptors. }\end{array}$ & $\begin{array}{l}\text { Schizophrenia was } \\
\text { associated with altered } \\
\text { glutamate levels, and } \\
\text { the administration of } \\
\text { glutamate NMDA } \\
\text { receptor antagonists in } \\
\text { healthy subjects } \\
\text { induced psychosis (Tsai } \\
\text { and Coyle, 2002). } \\
\text { The Grm3 locus was } \\
\text { linked to schizophrenia } \\
\text { in genetic association } \\
\text { studies, protein } \\
\text { expression altered in } \\
\text { patients in some studies } \\
\text { (Egan et al., 2004; } \\
\text { Harrison et al., 2008; } \\
\text { Schizophrenia Working }\end{array}$ & $\begin{array}{c}\text { Grm } 2 / 3 \text {-/- mice } \\
\text { have a full body } \\
\text { double knockout } \\
\text { of Grm2 and } \\
\text { Grm3 }\end{array}$ & $\begin{array}{c}\downarrow \text { Total sleep time } \\
\uparrow \text { Fragmented } \\
\text { sleep during light } \\
\text { phase }\end{array}$ & $\begin{array}{c}\uparrow \text { Period in LL } \\
\uparrow \text { Phase delays } \\
\text { after a light pulse } \\
\downarrow \text { Dark (active) } \\
\text { phase activity } \\
\text { under LD }\end{array}$ & $\begin{array}{c}\text { (Pritchett et al., } \\
\text { 2015) }\end{array}$ \\
\hline
\end{tabular}




\begin{tabular}{|c|c|c|c|c|c|c|}
\hline & & $\begin{array}{c}\text { Group of the } \\
\text { Psychiatric Genomics } \\
\text { Consortium, 2014). }\end{array}$ & & & & \\
\hline $\begin{array}{l}\text { Synaptosomal } \\
\text { Associated } \\
\text { Protein } 25 \mathrm{kDa} \\
\text { (Snap-25) }\end{array}$ & $\begin{array}{l}\text { The soluble } N \text { - } \\
\text { ethylmaleimide- } \\
\text { sensitive factor } \\
\text { attachment protein } \\
\text { receptor (SNARE) } \\
\text { complex and SNARE- } \\
\text { associated proteins } \\
\text { (such as SNAP-25) } \\
\text { have a role in the } \\
\text { docking of synaptic } \\
\text { vesicles at the } \\
\text { presynaptic terminal } \\
\text { membrane, resulting in } \\
\text { fusion and } \\
\text { neurotransmitter } \\
\text { release. }\end{array}$ & $\begin{array}{l}S N A P-25 \text { was linked to } \\
\text { schizophrenia in } \\
\text { genetic association } \\
\text { studies in certain } \\
\text { populations, and in } \\
\text { gene expression studies } \\
\text { (Fatemi et al., 2001; } \\
\text { Fanous et al., 2010). }\end{array}$ & $\begin{array}{c}\text { Snap-25 } \\
\text { heterozygote } \\
\text { mutants (blind- } \\
\text { drunk) have a } \\
\text { dominant } \\
\text { missense point } \\
\text { mutation in the } \\
\text { SNAP-25b } \\
\text { isoform, which } \\
\text { increases binding } \\
\text { characteristics of } \\
\text { SNAP-25 to the } \\
\text { SNARE complex } \\
\text { and alters } \\
\text { synaptic vesicle } \\
\text { release (Jeans et } \\
\text { al., 2007) }\end{array}$ & $\begin{array}{l}\text { No effect of the } \\
\text { mutation on sleep } \\
\text { (as recorded using } \\
\text { video tracking) }\end{array}$ & $\begin{array}{c}\text { Heterogeneity of } \\
\text { disruption: mild } \\
\text { disruption in most } \\
\text { mice, more } \\
\text { disruption in } \\
\text { others. } \\
\text { 个Light phase } \\
\text { activity and } \\
\uparrow \text { fragmentation } \\
\text { under LD (no } \\
\text { disruption in } \\
\text { DD/LL), } \\
\text { advanced phase of } \\
\text { entrainment. } \\
\text { Advanced } \\
\text { corticosterone and } \\
\text { vasopressin } \\
\text { rhythms }\end{array}$ & $\begin{array}{l}\text { (Oliver et al., } \\
\text { 2012) }\end{array}$ \\
\hline $\begin{array}{c}\text { Dysbindin-1 } \\
\text { (Dtnpbl) }\end{array}$ & $\begin{array}{l}\text { Biogenesis of } \\
\text { lysosome-related } \\
\text { organelles complex-1 } \\
\text { (BLOC-1) is a stable } \\
\text { protein complex that } \\
\text { consists of many } \\
\text { subunits including } \\
\text { Dysbindin-1 and } \\
\text { Pallidin (Ghiani and }\end{array}$ & $\begin{array}{l}\text { Genetic variants at the } \\
\text { Dtnbpl locus were } \\
\text { linked to schizophrenia } \\
\text { in genetic association } \\
\text { studies in certain } \\
\text { populations (Straub et } \\
\text { al., 2002; Schwab et } \\
\text { al., 2003). }\end{array}$ & $\begin{array}{l}\text { Dtnpb1 mutant } \\
\text { mice (Sandy) } \\
\text { have a natural } \\
\text { loss-of-function } \\
\text { mutation in the } \\
\text { Dtnbpl gene }\end{array}$ & Not tested & $\begin{array}{c}\uparrow \text { Free running } \\
\text { period, } \\
\uparrow \text { Subjective day } \\
\text { activity, } \\
\uparrow \text { Variable activity } \\
\text { onsets under LL } \\
\text { No disruption } \\
\text { under LD/DD. }\end{array}$ & $\begin{array}{c}\text { (Bhardwaj et al., } \\
\text { 2015) }\end{array}$ \\
\hline
\end{tabular}




\begin{tabular}{|c|c|c|c|c|c|c|}
\hline & $\begin{array}{l}\text { Dell'Angelica, 2011; } \\
\text { Mullin et al., 2011) } \\
\text { Dysbindin-1 is } \\
\text { involved in intracellular } \\
\text { membrane trafficking } \\
\text { and organelle } \\
\text { biogenesis (Falcon- } \\
\text { Perez et al., 2002). }\end{array}$ & $\begin{array}{c}\text { Dysbindin-1 mRNA } \\
\text { and protein expression } \\
\text { were reduced in } \\
\text { postmortem } \\
\text { schizophrenia brain } \\
\text { (Talbot et al., 2004; } \\
\text { Weickert et al., 2004; } \\
\text { Weickert et al., 2008; } \\
\text { Tang et al., 2009). } \\
\end{array}$ & & & & \\
\hline Pallidin & $\begin{array}{l}\text { Pallidin functions } \\
\text { exclusively as a } \\
\text { component of the } \\
\text { BLOC-1 complex and } \\
\text { is necessary for } \\
\text { promoting efficient } \\
\text { synaptic vesicle } \\
\text { recycling and re- } \\
\text { formation (Ghiani and } \\
\text { Dell'Angelica, 2011; } \\
\text { Chen et al., 2017) }\end{array}$ & $\begin{array}{l}\text { Through its activity in } \\
\text { the BLOC-1 complex, } \\
\text { and its interactions with } \\
\text { BLOC-1 subunits, } \\
\text { primarily Dysbindin-1, } \\
\text { pallidin may play a role } \\
\text { in neurodevelopmental } \\
\text { disorders (Ryder and } \\
\text { Faundez, 2009; } \\
\text { Hartwig et al., 2018). }\end{array}$ & $\begin{array}{l}\text { Palladin mutant } \\
\text { mice have a non- } \\
\text { sense mutation in } \\
\text { the Blos } 1 \text { s } 6 \text { gene } \\
\text { encoding Pallidin }\end{array}$ & $\begin{array}{l}\downarrow \text { Sleep time in the } \\
\text { beginning of light } \\
\text { phase } \\
\uparrow \text { Fragmented } \\
\text { sleep in LD }\end{array}$ & $\begin{array}{c}\text { Heterogeneity of } \\
\text { disruption: most } \\
\text { mice exhibiting } \\
\text { mild disruption, } \\
\text { while others were } \\
\text { dramatically } \\
\text { disrupted. } \\
\text { Variable activity } \\
\text { onsets, } \downarrow \text { Activity } \\
\text { under LD } \\
\\
\uparrow \text { Fragmented } \\
\text { activity, } \\
\downarrow \text { Precision and } \\
\uparrow \text { Subjective day } \\
\text { activity in DD. }\end{array}$ & (Lee et al., 2018) \\
\hline $\begin{array}{c}\text { SH3 and multiple } \\
\text { ankyrin repeat } \\
\text { domains } 3 \\
\text { (Shank3) }\end{array}$ & $\begin{array}{c}\text { SHANK3 is a } \\
\text { scaffolding protein } \\
\text { abundant in } \\
\text { postsynaptic densities } \\
\text { of excitatory synapses } \\
\text { (Sheng and Kim, 2000). }\end{array}$ & $\begin{array}{l}\text { Genetic association } \\
\text { studies link variants in } \\
\text { the } S H A N K 3 \text { gene to } \\
\text { autism spectrum } \\
\text { disorder and } \\
\text { schizophrenia (Gauthier } \\
\text { et al., 2010; de Sena }\end{array}$ & $\begin{array}{l}\text { Shank } 3^{\Delta C} \text { mutant } \\
\text { mice have a } \\
\text { deletion in exon } \\
21 \text { of this gene }\end{array}$ & $\begin{array}{l}\downarrow \text { Sleep time and } \\
\downarrow \text { Sleep intensity in } \\
\text { dark period of LD. } \\
\text { Delayed sleep } \\
\text { onset following 5- }\end{array}$ & $\begin{array}{l}\downarrow \text { Total activity in } \\
\text { DD } \\
\text { No disruption } \\
\text { under LD }\end{array}$ & $\begin{array}{c}\text { (Ingiosi et al., } \\
2019)\end{array}$ \\
\hline
\end{tabular}




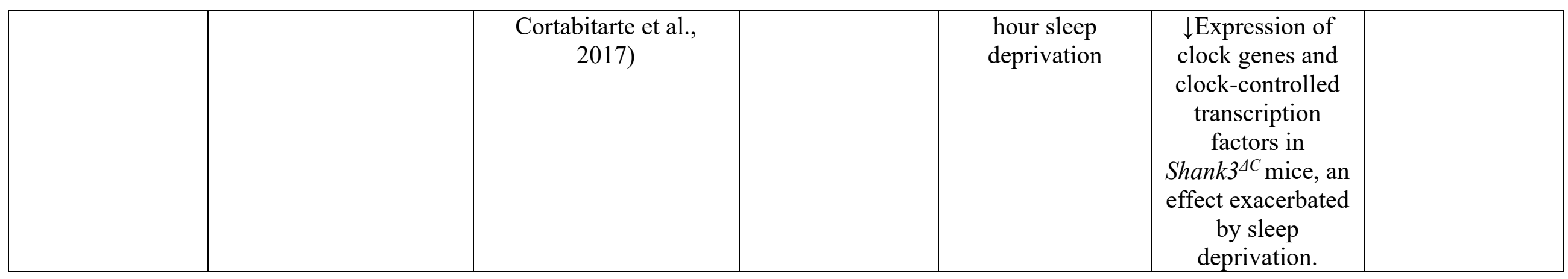

NREM, non rapid eye movement sleep; REM, rapid eye movement sleep; LD, light-dark cycle; DD, constant darkness; LL, constant light; Alpha, duration of the activity phase 




\section{Schizophrenia}
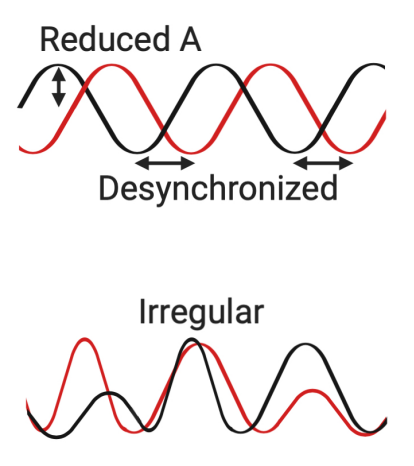


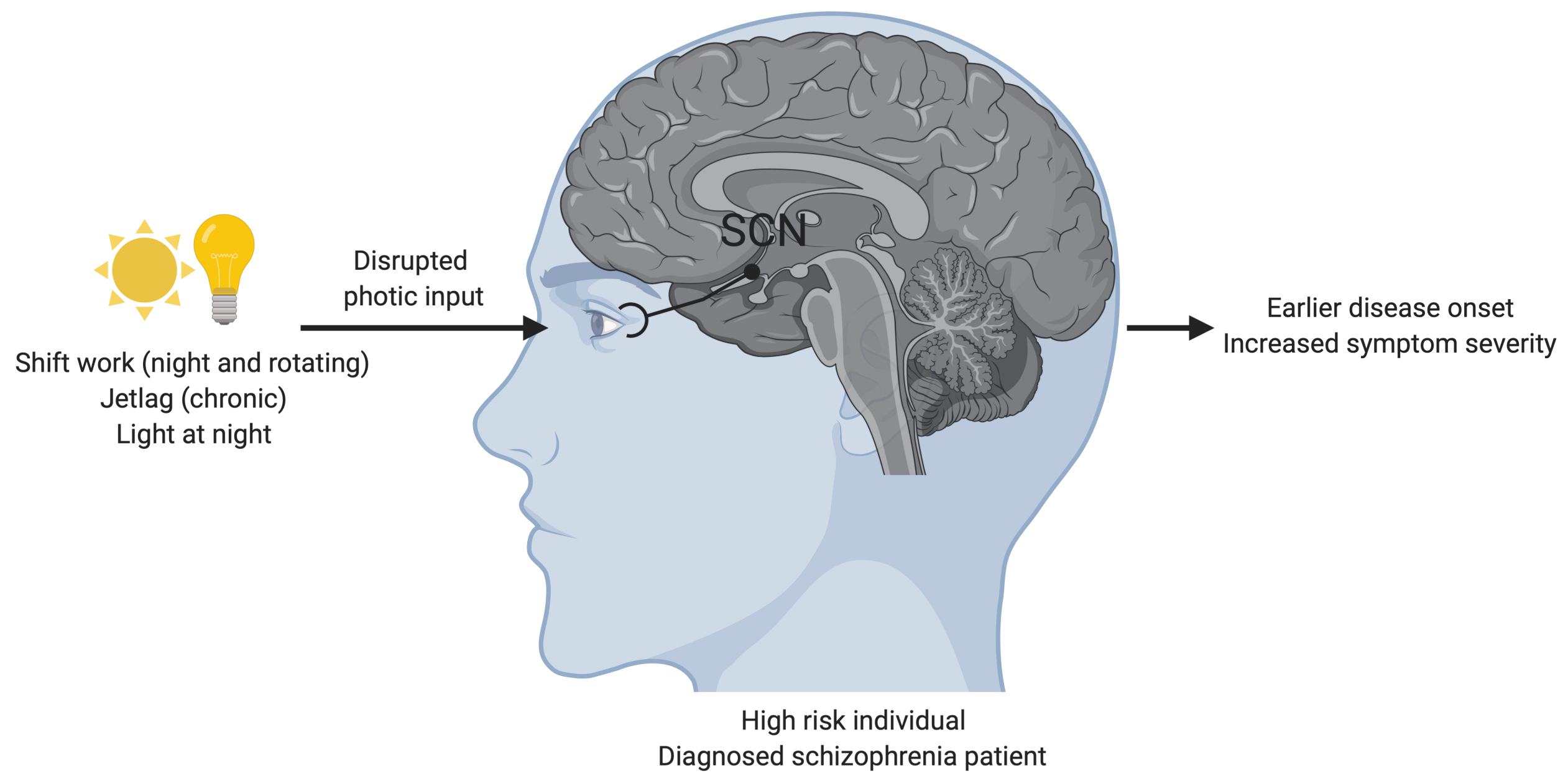

